\title{
MODERN INTEGRATED PLATFORM MANAGEMENT SYSTEM LABORATORY FOR POLISH NAVAL ACADEMY: DESIGN ANDIMPLEMENTATION
}

\section{Rafał Warżała $\mathbb{B}$}

Research and Development Center Maritime Technology Center, A. Dickmana 62 Str., 81-109 Gdynia, Poland; e-mail: rafal.warzala@ctm.gdynia.pl; ORCID ID: 0000-0003-4461-7320

\begin{abstract}
This article contains a description of the implemented STANTOS ${ }^{\mathrm{TM}}$ Integrated Platform Management System (IPMS) laboratory created by Research and Development Center Maritime Technology Center for the Polish Naval Academy in Gdynia. The author briefly described the topology of the solution, justifies the choice of hardware and software solutions. Concept of use was written, where the usefulness of the implemented laboratory was motivated, with a focus on cases where safety plays a key role.
\end{abstract}

Keywords:

STANTOS, Integrated Platform Management System, IPMS, automation system, maritime.

Research article

(c) 2020 Rafał Warżała

This is an open access article licensed under the Creative Commons Attribution-NonCommercial-NoDerivatives 4.0 license (http://creativecommons.org/licenses/by-nc-nd/4.0/) 


\section{INTRODUCTION}

An Integrated Platform Management System (IPMS) is used on board of naval vessels with automated systems for real-time monitoring and control. A common solution is to control and monitor the status of systems such as propellers, fire-fighting, engines and their support systems, ventilation, fuel, etc. Major manufacturers of industrial automation and ship equipment (such as ABB, Kongsberg, Honeywell) offer such systems. As M. H. Ghaemi describes in his materials: '[...] the factors determining the degree of automation are the result of an economic calculation as well as sociological and psychological considerations. The reason for automation is replacing and simultaneously improving human work, as well as increasing the level of reliability and safety. Automation may be necessary, especially when it comes to automatic regulation, cooperation with the superior system, quick processing of a large amount of information or optimization of the engine's operation. Ultimately, automation results in a reduction of crew size' [1]. Often, the degree of automation is imposed by the classification environment or the shipowner's requirements [6]. Despite the increasing degree of automation and the reduction in the number of crew (accompanied by an increase in its competence) is essential. Assuming that the faster a crewman acquires knowledge and skills, the better it is, naval school would be the optimal place to gain these abilities. Naval Academy in Gdynia states that its graduates will be prepared to make operational decisions in difficult, maritime conditions concerning the use of vessel's power plant, as well as in extreme combat conditions. Graduates will also have qualifications covering knowledge of operation and operation of propulsion [8]. An academy preparing students for work at sea should consider that nearly half of accidents at sea are caused by the human factor [12]. The Academy, aware of the importance of proper crew training on simulators, decided to create an IPMS laboratory. Ośrodek Badawczo-Rozwojowy Centrum Techniki Morskiej S.A. - OBR CTM S.A. (Research and Development Center Maritime Technology Center) responded to this demand by proposing the implementation of its STANTOS $^{\text {TM }}$ System. The STANTOS ${ }^{\text {TM }}$ Software is a modern SCADA (Supervisory Control And Data Acquisition) system that supervises the operation of ship systems. Its tasks include presenting current and archival measurements of ship system sensors as well as alarm signals. The system performs all functions of alarm and control, data management, displaying event history logs and allows to create independent applications that manage industrial automation. The basic 
design assumption was to enable simulation of a real, modern platform management system. STANTOS ${ }^{\text {TM }}$ consists of elements used to simulate the technical and software components of IPMS systems. While working on a dedicated solution, SIMATIC tool and Inkscape SAGE licensed commercial software were used. This system enables the set up and modification of hardware and software configuration to achieve the required teaching objectives related to both the design of marine IPMS systems as well as their technical support (supervision and repairs). Actuators are simulated in the software and modelled in the hardware layer by using a number of basic automation components. This allows the Academy to provide courses on a very wide range of topics: from the design and implementation of basic IPMS subsystems, through connecting subsystems into a network, to the operation of a simulated IPMS system [4]. In the next section design of laboratory is presented. Then, the hardware and software solution is shown and at the end concept of use was described.

\section{DESIGN}

The main advantages of distributed systems are such features as: role distribution, resource sparing, system reliability, process concurrency, scalability and fault tolerance [5]. Therefore, it was decided to implement the automation system in a distributed type. Fig. 1 shows system topology.

Each automation workstation is responsible for a dedicated ship system and connected together in architecture based on the Ethernet ring topology. Architecture of this type has an increased resistance to failures, which allows for efficient operation of the system even after malfunction or damage to some of its elements, e.g. cables or network switches. STANTOS ${ }^{\mathrm{TM}}$ has a modular structure, giving the possibility of easy configuration of software and hardware components building appropriate functionalities dedicated to specific customer needs. The software is based on the universal SEFCOM (Sensor Effector Communicator) framework, which is the basis of other ship systems implemented by OBR CTM S.A. (Research and Development Center Maritime Technology Center). 


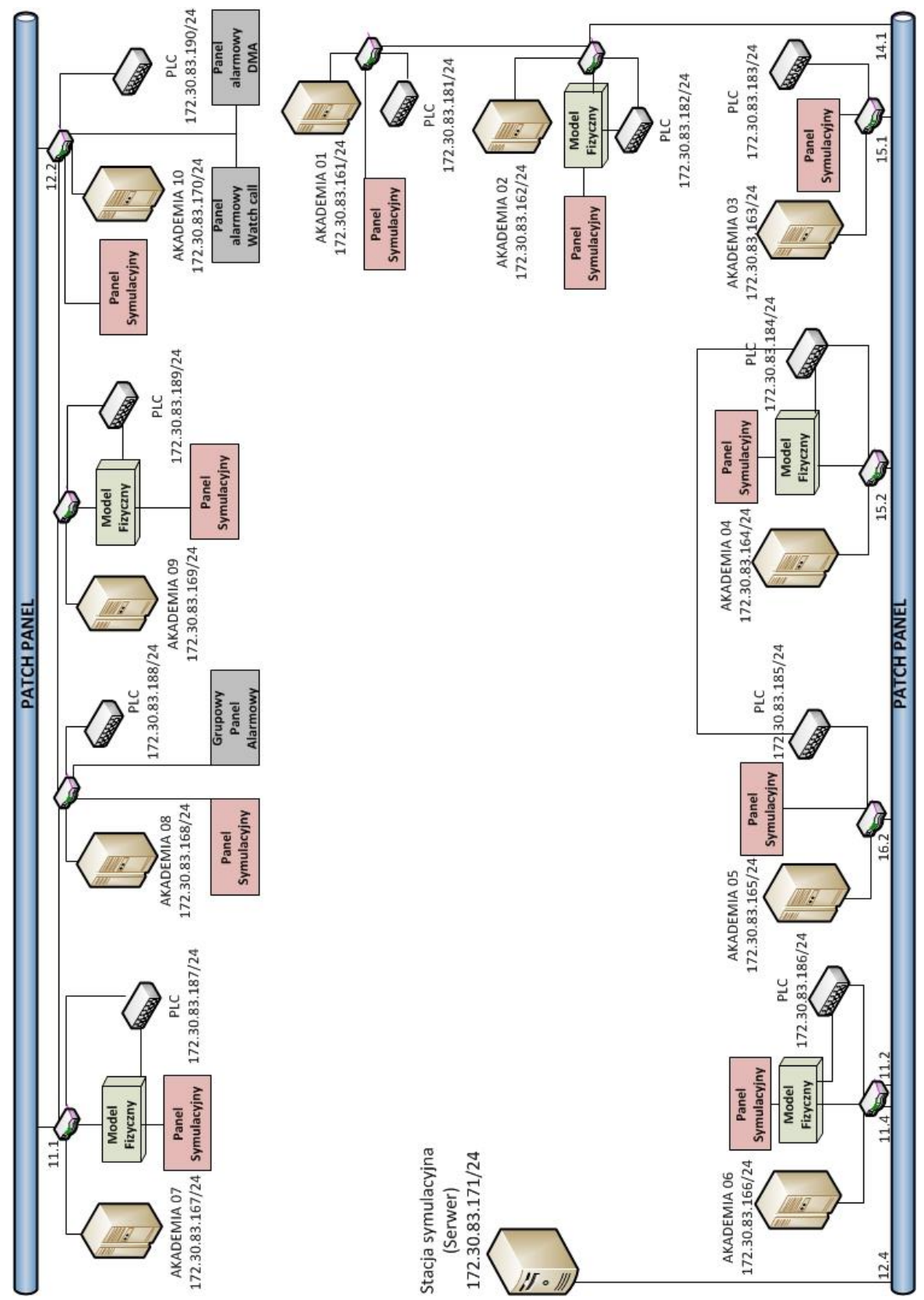

Fig. 1. STANTOS ${ }^{\text {TM }}$ System topology consisting of blocks:

panel symulacyjny (Simulation Console), model fizyczny (Physical Model), grupowy panel alarmowy (Group Alarm Panel), panel alarmowy Watch Call (Watch Call Alarm Panel), panel alarmowy DMA (Dead Man Alarm Panel), stacja symulacyjna (Simulation Station) [4] 


\section{HARDWARE}

The STANTOS ${ }^{\text {тм }}$ System consists of the following components (fig. 1): 10 Workstations with STANTOS ${ }^{\text {тм }}$ Software, 10 Simulation Panels, 10 PLC Controllers, 5 Physical Models, 1 Simulation Station (STANTOS ${ }^{\text {тм }}$ Server), 1 'Deadman' Alarm Panel, 1 'Watch Call' Alarm Panel, 1 Group Alarm. Each of the 10 laboratory stations is equipped with an automation set (fig. 2). All elements of automation are connected with each other by a fast, industrial automation network, allowing mutual communication.

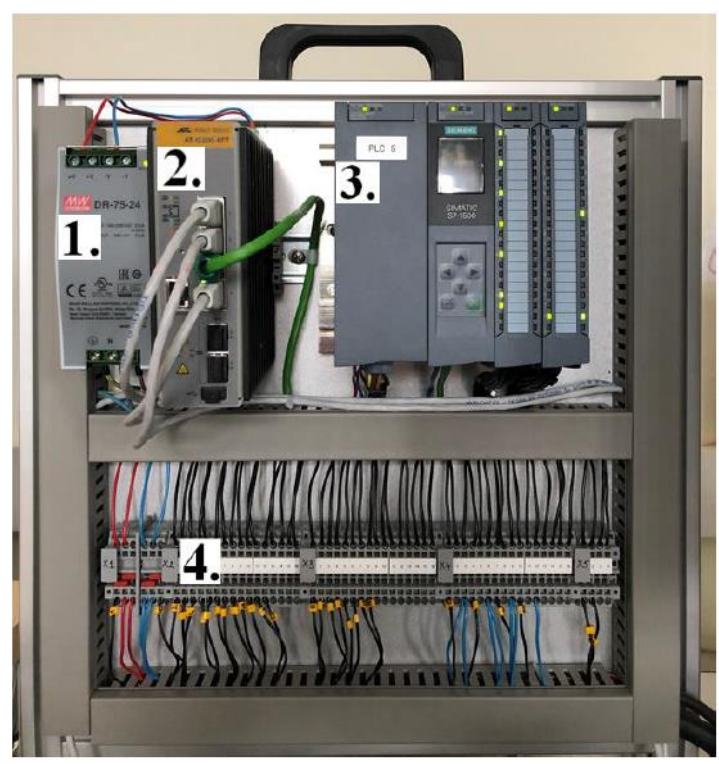

Fig. 2. Photo of rack with automation set where:

1. Power Supply, 2. Switch, 3. PLC S7-1500, 4. Junction Strips [4]

PLC Controllers can be programmed to work with Physical Models and Simulation Panels using the SIMATIC tool software. Physical Models are a mapping of real ship systems, but they are simplified representations in the scope that allows to understand the mechanisms of system operation and to conduct laboratory exercises. Physical Models generate appropriate signals, which after processing by PLC Controllers are received by the STANTOS ${ }^{\text {тм }}$ System and visualized as events of real ship systems. Physical Models respond to control signals generated from Workstations. The set of Physical Models represents 5 different ship systems: ballast, ventilation, fuel, fire-fighting and oil. 
Simulation Panels are devices that generates simple digital and analogue signals for simulating signals from marine equipment and systems. These signals are received by I/O modules of PLC Controllers and processed for presentation in SCADA software or STANTOS ${ }^{\text {тм }}$ System as signals of real devices.

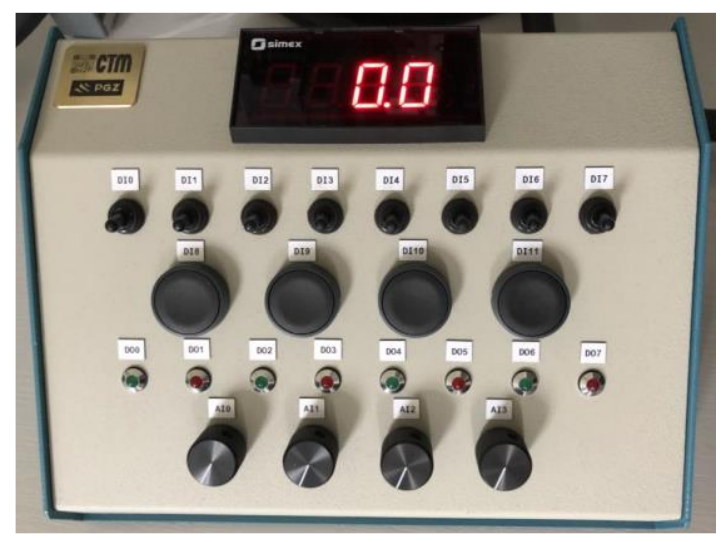

Fig. 3. Photo of Simulation Panel [4]

Simulation Panels (fig. 3) by working in a shared network can present events simulated by the Simulation Station or events developed by other laboratory stations using their own simulation panel.

The Deadman Alarm (DMA) panel is used to monitor and supervise the presence of machine personnel in the ship's power plant in unattended operation mode. The appearance of the 'Deadman Alarm' alarm panel is shown in fig. 4 and 5 shows an example of a commercial DMA panel.

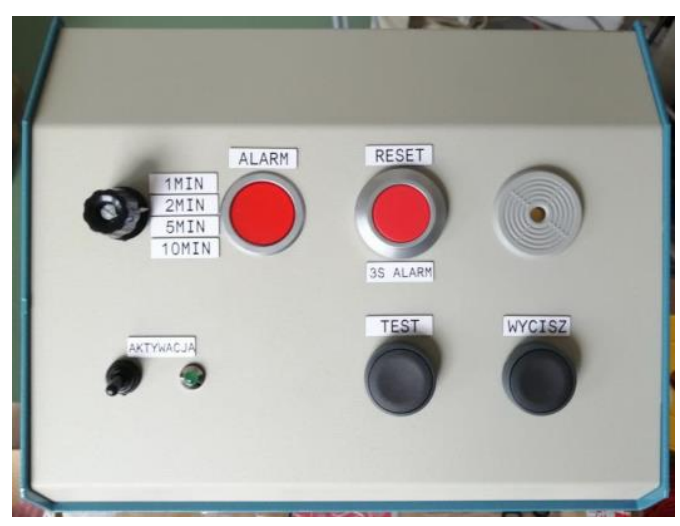

Fig. 4. Photo of Deadman Alarm Panel [4]

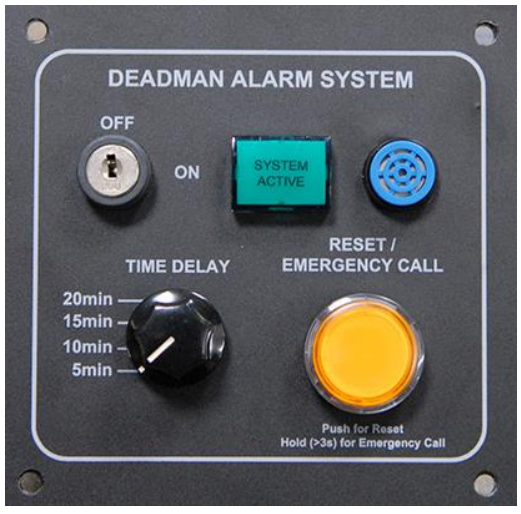

Fig. 5. Photo of commercial DMA panel [10] 
The Group Alarm Panel is used to signal alarm states from selected Alarm Groups. This panel is equipped with lights signalling an alarm. Panels of this type are usually placed in the navigation cabin and the ship's engine control centre. Figures presented below compare a Group Alarm Panel made by OBR CTM S.A. and a commercial version.

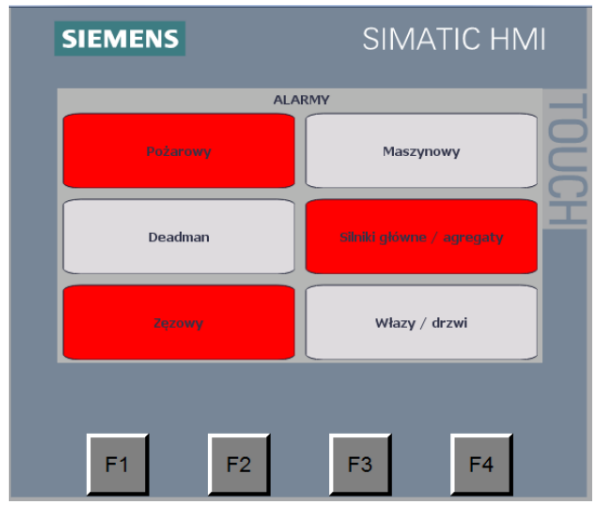

Fig. 6. Photo of Group Alarm Panel [4]

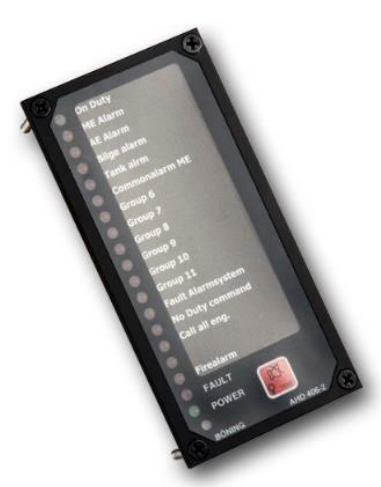

Fig. 7. Photo of Commercial Group Alarm Panel [9]

The Watch Call System is designed to inform the watch mechanic about the occurrence of an alarm condition or warnings. Panels of this type are usually placed in social rooms (e.g. a mess room) and in the crew quarters. Fig. 8 and 9 present a Call Panel made by OBR CTM S.A. and a commercial version.

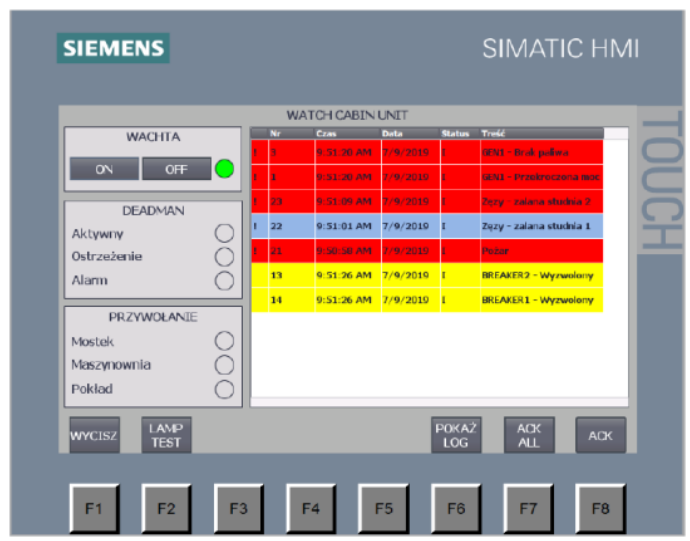

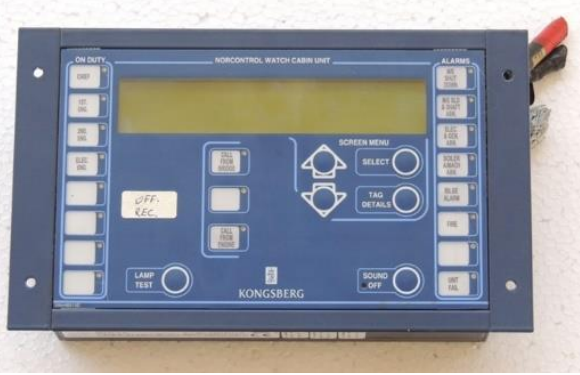

Fig. 9. Photo of commercial Watch Call Panel [11]

Fig. 8. Photo of Watch Call Panel [4] 


\section{SOFTWARE}

In addition to the STANTOS ${ }^{\mathrm{TM}}$ Software, Inkscape SAGE has been installed on each operator console. Inkscape SAGE is a powerful tool for designing and visualizing software components. The design version allows an efficient design of advanced applications and has the necessary symbols library designed to create perspectives in the field of industrial and process automation. User can also expand STANTOS ${ }^{\mathrm{TM}}$ with new perspectives or elements. It is also possible for the user to create his own applications.

Each of 10 PC workstations with STANTOS ${ }^{\mathrm{TM}}$ Software has an Ethernet connection with the simulation station. Exchange of information between them is possible through a STANTOS ${ }^{\mathrm{TM}}$ Server located at the simulation station. To ensure reliable operation and continuous synchronization between system components, the Network Time Protocol is employed. A simulation station is also used as a time server which periodically provides time synchronization in the system with a period of one minute.

To provide the scalability of the project and efficiency of data exchange between consoles and PLC (through the STANTOS ${ }^{\mathrm{TM}}$ Server) it was decided to use the OPC UA protocol. An OPC server has been activated on each of the 10 PLCs. STANTOS $^{\text {TM }}$ Communicator is a client for these servers and a is a type of a 'translator' of protocol for the server. STANTOS ${ }^{\text {тM }}$ Simulator perspective is shown in fig. 10.

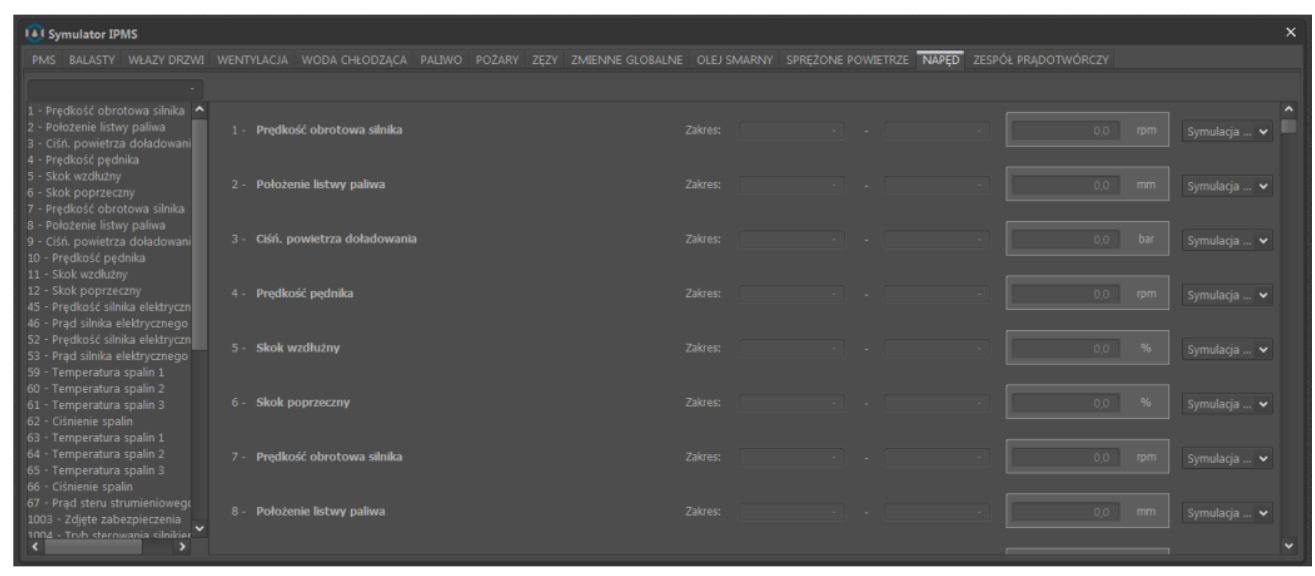

Fig. 10. STANTOS ${ }^{\mathrm{TM}}$ Simulator view [4]

The simulator software, which is located on the simulation station, performs all simulation and training functions of the Integrated Platform Management System. Alarm events of simulated ship devices are generated at the Simulation Station. Both analogue and digital values of simulated sensors and measuring devices can be set. 
After launching the STANTOS ${ }^{\text {тм }}$ Application on the operator's console and logging in, a navigation panel will appear to move between perspectives. In addition to the System and Trends tab, each perspective corresponds to individual systems simulated for the needs of the laboratory.

\section{CONCEPT OF USE}

The efficiency of the engine room is critical to the ship's manoeuvrability. Losing it may lead to losses due to the destruction of the vessel and port infrastructure. What might be the consequences of a blackout on a ship is shown in the MV Planet V case study, where one of the sailors lost his life [2]. As Damir Radan proves in his doctoral dissertation: Power Management System interacts with the propellers by the following functions: available power static load control, load rate limiting control and blackout prevention control. These functions serve to prevent the blackout and to ensure that the vessel will always have enough power available [7]. In the STANTOS ${ }^{\mathrm{TM}}$ System, the power supply system has been modelled as a central energy distribution system. Energy from two generators is transferred directly to the main switchboard. The main switchboard is divided into two sections connected by bus-tie (breaker connecting electric bars between sections). Electrical supply perspective is shown in fig. 11.

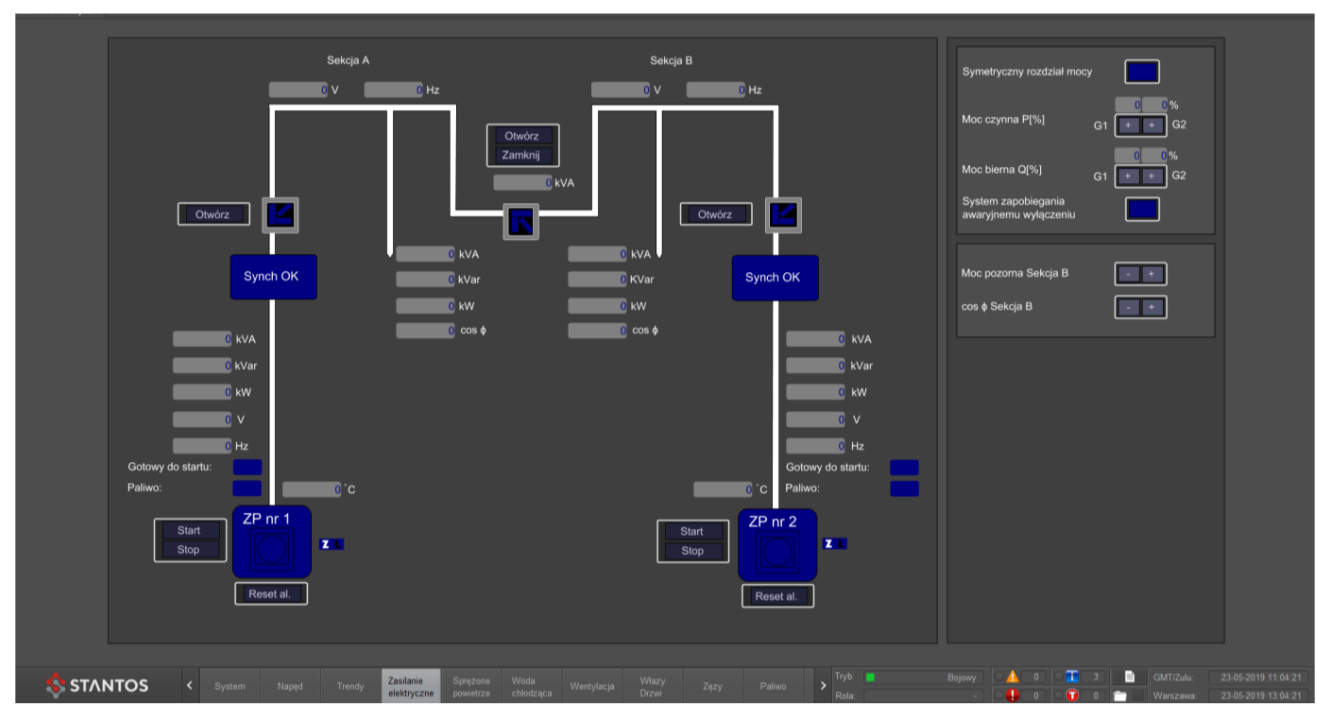

Fig. 11. View at Power Supply Perspective [4]

$1-2(220 / 221) 2020$ 
STANTOS $^{\text {тм }}$, as a useful teaching tool, enables the student to get acquainted with the work of the Power Management System. In the event of a system failure one can find in Trends tab what were the parameters of individual elements of the system at any given time instance, and there is an information of active warnings and alarms and a log of their history on the alarm panel. This allows to gain experience with dealing with this kind of failures and to train one in correctly diagnosing the system. Among other functionality, it is possible to simulate the running after blackout, automatic and manual synchronization of individual generating sets. Using STANTOS ${ }^{\mathrm{TM}}$, the student will learn how to avoid blackout and practice the correct sequence of activities needed to be performed.

Raising the degree of vessel's functions automation positively affects the sociological aspect of crew work comfort. However, it should be remembered that safety is a priority in the maritime industry. That is why classification environments allow for unattended operation of the machinery, but this matter is secured with many specific restrictions $[3,6]$. One of these requirements is to provide detection of increasing of level of water in the engine room bilges or bilge wells. The student can simulate the flooding of wells to get the experience of handling in case of such situation occurring on the vessel.

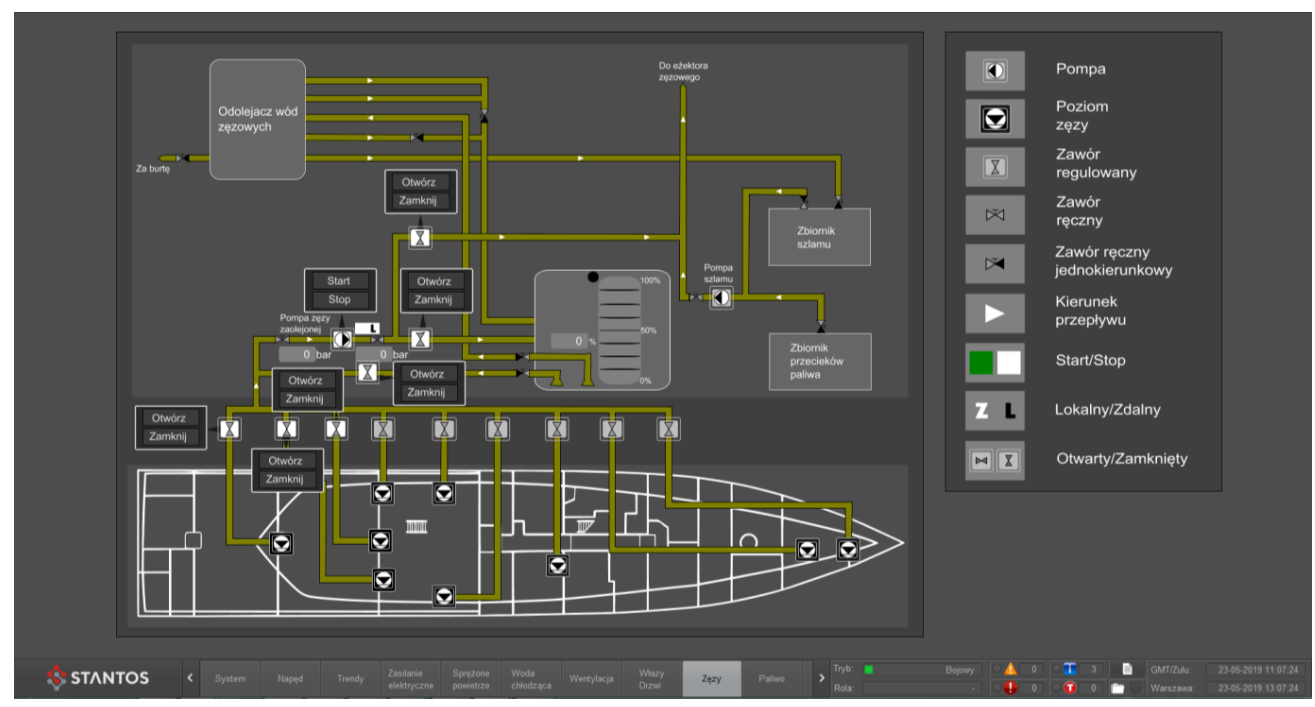

Fig. 12. View at Bilge Perspective [4]

Another classification environment safety requirement that directly affects human health and life is the operation of the Dead Man / Patrol Man System. Lloyd's 
requires the alarm system to be reset at predetermined intervals (e.g. each 30 minutes) [3]. If the Dead Man panel is active and there is no reset after the set time interval, an alarm will be signalled locally. Information about the warning and the alarm will also appear on the alarm panel. Using this system in the laboratory will allow the student to develop the habit of taking care of his own safety by using devices and systems serving this purpose.

\section{CONCLUSIONS}

The project of the IPMS system, its design solutions and the justification for the chosen topology were described in this article. Selection of hardware was first determined by its educational value. Other objectives were to allow to sustain scalability of hardware and provide possibilities to expand project. The main goal of using STANTOS ${ }^{\mathrm{TM}}$ is education, becoming familiar with the principles of IPMS and to gain proper habits, especially in emergency situations. Moreover, the functional use aspect of the application's operation was maintained - data is read from real sensors, and real actuators are activated. The software used here allows the student to become familiar with the graphic interface used by OBR CTM S.A. in other products, such as Combat Management Systems. Laboratory project was design as open-source type of educational tool. This system can be expanded for example by a graduating student during his diploma thesis. One particular area of future development is the integration with other Academy laboratories, allowing to exchange data between them. This system has great educational value, supporting students in understanding bigger systems and processes.

\section{Acknowledgments}

Laboratory was made by Ośrodek Badawczo-Rozwojowy Centrum Techniki Morskiej S.A. (Research and Development Center Maritime Technology Center).

\section{REFERENCES}

[1] Ghaemi M. H., Podstawy automatyzacji okrętu. Techniczne, ekonomiczne i socjologiczne aspekty automatyzacji okrętu, Gdańsk 2018 [Ship autopation basics. Technical, economic and sociological aspects of ship automation — available in Polish]. 
[2] Hasegawa K., Ibn Awal Z., Analysis of Ship Accidents due to Marine Engine Failure - Application of Logic Programming Technique, 'Journal of the JIME', 2015, Vol. 50, No. 6, pp. 40-46.

[3] Jong I. W. de, Machinery Alarm Systems for Ships Operated with Unattended Machinery Spaces, Lloyd's Register of Shipping, Rotterdam 1973.

[4] Laboratorium IPMS Akademii Marynarki Wojennej. Instrukcja użytkowania oprogramowania STANTOS $^{\text {TM }}$, Research and Development Center Maritime Technology Center, 2019 [IPMS Laboratory of the Naval Academy. STANTOS ${ }^{\text {TM }}$ Software user manual — available in Polish].

[5] Mosorow W., Systemy rozproszone, Lodz University of Technology, Łódź, 2007 [Distributed systems — available in Polish].

[6] Przepisy klasyfikacji i budowy okrętów wojennych, cz. VIII, Instalacje elektryczne i systemy sterowania, Polski Rejestr Statków, Gdańsk 2008 [Standards for the classification and construction of warships, Part VIII, Electrical installations and control systems - available in Polish].

[7] Radan D., Integrated Control of Marine Electrical Power Systems, PhD Thesis, Norwegian University of Science and Technology, Trondheim 2008.

[8] Sylwetka absolwenta wojskowego, [online], http://www.wme.amw.gdynia.pl/dla-studentow/ sylwetka-absolwenta/sylwetka-absolwenta-wojskowego [access 05.01.2020], [Military graduate profile - available in Polish].

[9] Website 'Böning Automationstechnologie GmbH \& Co. KG', [online], https://www.boening.com/ ahd_406-2.html?\&L=1 [access 05.01.2020].

[10] Website 'Pan Delta Controls PTE LTD', [online], https://www.pandelta.com/ [access 05.01.2020].

[11] Website 'Ship automation', [online], https://www.shipautomation.com/product/kongsbergwatch-cabin-unit-display/ [access 05.01.2020].

[12] Wypadki i incydenty morskie. Roczna analiza, State Marine Accident Investigation Commission, 2017 [Marine accidents and incidents. Annual analysis — available in Polish].

\section{NOWCZESNE LABORATORIUM ZINTEGROWANEGO SYSTEMU ZARZĄDZANIA PLATFORMĄ DLA POLSKIEJ AKADEMII MARYNARKI WOJENNEJ: PROJEKT I WDROŻENIE}

\section{STRESZCZENIE}

Artykuł zawiera opis wdrożonego laboratorium zintegrowanego systemu zarządzania platformą (IPMS) STANTOS ${ }^{\text {TM }}$ stworzonego przez Ośrodek Badawczo-Rozwojowy Centrum Techniki Morskiej S.A. dla Akademii Marynarki Wojennej w Gdyni. Autor krótko opisał topologię rozwiązania, uzasadniając wybór rozwiązań sprzętowych i programowych. Napisano koncepcję użytkowania, 
Modern integrated platform management system laboratory for Polish Naval Academy...

w której uzasadniano przydatność wdrożonego laboratorium, ze szczególnym uwzględnieniem przypadków, w których bezpieczeństwo odgrywa kluczową rolę.

\section{Słowa kluczowe:}

STANTOS, zintegrowany system zarządzania platformą, IPMS, system automatyki, technika morska.

Article history

Received: 01.03 .2020

Reviewed: 24.04 .2020

Revised: $\quad 13.05 .2020$

Accepted: $\quad 05.06 .2020$ 